\title{
Selective Tradition and Structure of Feeling in the 2008 Presidential Election: A Genealogy of "Yes We Can Can"
}

\author{
BRUCE CURTIS
}

\begin{abstract}
I examine Raymond Williams's concepts "structure of feeling" and "selective tradition" in an engagement with the novel technical-musical-cultural politics of the 2008 Barack Obama presidential election campaign. Williams hoped structure of feeling could be used to reveal the existence of pre-emergent, counter-hegemonic cultural forces, forces marginalized through selective tradition. In a genealogy of the Allen Toussaint composition, "Yes We Can Can," which echoed a key campaign slogan and chant, I detail Toussaint's ambiguous role in the gentrification of music and dance that descended from New Orleans's commerce in pleasure. I show that pleasure commerce and struggles against racial segregation were intimately connected. I argue that Toussaint defanged rough subaltern music, but he also promoted a shift in the denotative and connotative uses of language and in the assignments of bodily energy, which Williams held to be evidence of a change in structure of feeling. It is the question of the counter-hegemonic potential of subaltern musical practice that joins Raymond Williams's theoretical concerns and the implication of Allen Toussaint's musical work in cultural politics. My address to the question is suggestive and interrogative rather than declarative and definitive.
\end{abstract}

Barack Obama's 2008 American presidential election and the post-election celebrations were the first to be conducted under the conditions of "web 2.0," whose rapid spread from the mid-2000s is a historic "cultural break" similar in magnitude and consequence to the earlier generalization of print culture. ${ }^{1}$ In Stuart Hall's terms, such breaks are moments in which the cultural conditions of political hegemony change. ${ }^{2}$ They are underpinned by changes in technological forces, in relations of production and communication. They involve novel forms of popular cultural upsurge and novel attempts by political authorities at provocation, education, and recuperation. The Obama campaign, through clever tactics, new communication technology, and cosmopolitan capitalist trends, ${ }^{3}$ incorporated a mix of marginal, potentially oppositional, and residual cultural elements in a successful (if unstable and ultimately fleeting)

\footnotetext{
${ }^{1}$ Cheris A. Carpenter, “The Obamachine: Technopolitics 2.0," Fournal of Information Technology E Politics 7, no. 2-3 (2010): 216-25, https://doi.org/10.1080/19331681003765887; Derrick L. Cogburn and Fatima K. Espinoza-Vasquez, "From Networked Nominee to Networked Nation: Examining the Impact of Web 2.0 and Social Media on Political Participation and Civic Engagement in the 2008 Obama Campaign," Fournal of Political Marketing 10, no. 1-2 (2011): 189-213, https://doi.org/10.1080/15377857.2011.540224; Dana Gorzelany-Mostak, “Keepin' It Real (Respectable) in 2008: Barack Obama's Music Strategy and the Formation of Presidential Identity," Fournal of the Society for American Music 10, no. 2 (2016): 113-48, https://doi.org/10.1017/S1752196316000043.

2 Stuart Hall, "Popular culture, politics and history," Cultural Studies 32, no. 6 (2018): 929-52, https://doi.org/10.1080/09502386.2018.1521623.

${ }^{3}$ Linda F. Selzer, "Barack Obama, the 2008 Presidential Election, and the New Cosmopolitanism: Figuring the Black Body," MELUS 35, no. 4 (2010): 15-37, https://doi.org/10.1093/melus/35.4.15.
} 
effort to forge political solidarities. Vernacular musical culture played an unusually important role in this process, as the campaign worked to forge a musical-political coalition. ${ }^{4}$

This article makes a theoretical and a genealogical contribution to the already massive literature on the 2008 election. I both use and interrogate Raymond Williams's related concepts "structure of feeling" and "selective tradition" to engage with the novel technical-musical-cultural politics of the Obama campaign. I add to the literature on the campaign's and the candidate's music-cultural selections and exclusions through a genealogy of the Allen Toussaint composition, "Yes We Can Can," which echoed a key campaign slogan and chant. ${ }^{5}$ Williams hoped structure of feeling could be used to reveal the existence of counter-hegemonic cultural forces before they were fully formed, but offered little methodological guidance in this regard. Nonetheless, he suggested that a shift in structure of feeling might be detected through shifts in denotative and connotative uses of language and in the formation of collective energy.

In a genealogy of "Yes We Can Can," I point to Toussaint's role in the shifting meanings of "funk" and "funky." In the 1960s and early 1970s, earlier connotations of filth and disease, and racist claims about malodorous black bodies, were inverted, especially in the musical mainstream. Former epithets became sources of pride and marks of "cool." For Williams, a marked shift in the relations between signifier and signified is one indication of a change in structure of feeling. Perhaps the shift also countered an earlier twentieth century change, discussed by Mara Keire, in which dominant discourses came to treat sexually active women as disease vectors and the language of the street increasingly reduced women to their organs of pleasure and reproduction. ${ }^{6}$ Yet Toussaint's work both descended from and sanitized lyrics and performance that Howard Odum and Guy Johnson denounced as "the superlative of the repulsive." ${ }^{7}$ And Keire herself points to the ways in which pleasure commerce involved an "aesthetics of excess" that challenged bourgeois morality. ${ }^{8}$ It is the question of the counter-hegemonic potential of subaltern and vernacular musical practice that joins Raymond Williams's theoretical concerns and the implication of Allen Toussaint's musical work in cultural politics. My address to the question is suggestive and interrogative rather than declarative and definitive.

\section{Culture Shift and Structure of Feeling}

Joseph Lowery's benediction at Barack Obama's 2009 US presidential inauguration is emblematic of

\footnotetext{
${ }^{4}$ Music-making has been significant in virtually all presidential election campaigns, but the field of musical intervention changed dramatically with Web 2.0, because it gave access to new means of communication to huge numbers of people, and because it allowed for new kinds of social and political interaction. For extensive references on past campaigns, see Dana Gorzelany-Mostak and James Deaville, "On the Campaign Trail(er): Deconstructing the Soundscape of the 2012 US Presidential Election,” Music \& Politics 9, no. 2 (2015): 1-14, https://doi.org/10.3998/mp.9460447.0009.201. As I write, candidates in the US primary season and President Trump in his early re-election moves are routinely generating playlists to flag their political loyalties and to energize potential electors. For a list and some analysis, see "What the Rally Playlists Say About the Candidates," New York Times, August 21, 2019.

${ }^{5}$ On genealogy as method, with reference to musical intuition and tradition, Chandra Mukerji, "Cultural Genealogy: Method for a Historical Sociology of Culture or Cultural Sociology of History," Cultural Sociology 1, no. 1 (2007): 49-71, https://doi.org/10.1177/1749975507073919. On the origins of the slogan, see note 49 below.

${ }^{6}$ Mara L. Keire, For Business and Pleasure: Red-Light Districts and the Regulation of Vice in the United States, 1890-1933 (Baltimore: Johns Hopkins University Press, 2010), 108-11; "Swearing Allegiance: Street Language, US War Propaganda, and the Declining Status of Women in Northeastern Nightlife, 1900-1920," Fournal of the History of Sexuality 25, no. 2 (2016): 246-66, https://doi.org/10.7560/JHS25202.

${ }^{7}$ Howard W. Odum and Guy B. Johnson, The Negro and His Songs: A Study of Typical Negro Songs in the South (Raleigh:

University of North Carolina Press, 1925), 166.

${ }^{8}$ Keire, For Business, 28.
} 
an elevation of subaltern musical practice to political prominence. Lowery, the then 87-year-old founder of the Southern Christian Leadership Conference, a living icon and a leading activist of the midtwentieth-century US civil rights movement, concluded:

Lord, in the memory of all the saints who from their labors rest, and in the joy of a new beginning, we ask you to help us work for that day when black will not be asked to get back, when brown can stick around; when yellow will be mellow; when the red man can get ahead, man, and when white will embrace what is right. Let all those who do justice and love mercy say amen. Say Amen. Say Amen. ${ }^{9}$

This mild invocation of a post-racial future provoked eruptions of rage in the blogosphere, with many Republicans and fundamentalist Christians denouncing a racist insult to all Americans. ${ }^{10}$ Other observers noticed that Lowery was riffing on a 1945 Big Bill Broonzy song, "Black, Brown, and White" (sometimes titled "Get Back") which denounced Jim Crow politics. With his chorus of: "If you're white, it'll be all right / if you're brown you can stick around / but if you're black, oh brother, get back, get back, get back," Broonzy sang of being refused service in bars, rejected for employment, of being hired at half the pay of his white line mates, and so on. Many versions ended with the singer's refusal to "get back" after his contribution to the war effort and challenged "Mr. Charlie" to get rid of Jim Crow. During a period of segregated "race record" catalogues, several companies refused Broonzy's attempts to record the song, on the grounds that it was offensively political. Only in 1958, the year of Broonzy's death, was a 1952 Mercury recording released. ${ }^{11}$ In 2009, this formerly excoriated cultural product-once a "nonincorporated cultural residual," in Raymond Williams's terms-was used in the ritual consecration of central state power in the world's imperium. ${ }^{12}$

The elevation of this composition was part of the selective legitimation and political mobilization of African American musical creativity in the 2008 election campaign and post-election inaugurals. Other forms of musical creativity were also mobilized, but I suggest that in selectively legitimating African American music the campaign both tapped into and temporarily gave form to a latent structure of feeling.

\footnotetext{
${ }^{9}$ The presence of the progressive Lowery was counterbalanced by the inaugural committee's bow to evangelicals by having Rick Warren offer the prayer of invocation. Janet R Jakobsen and Ann Pellegrini, “Obama's Neo-New Deal: Religion, Secularism, and Sex in Political Debates Now," Social Research: An International Quarterly 76, no. 4 (2009): $1227-54$.

${ }^{10}$ For the text and the reaction of the radical right to Lowery, see https://thinkprogress.org/beck-outraged-at-inaugurationbenediction-accuses-rev-lowery-of-calling-america-racist-951113bc7953/.

${ }^{11}$ The song was radical in Joseph Lowery's youth, but extremely mild politically in 2008. It circulated outside hegemonic cultural circles but was available as a political resource under certain conditions. The lyrics appeared in a labourite publication in 1946 and it was recorded on minor record labels by Brownie McGhee in 1947 and by Pete Seeger in 1948. Ellen Harold and Peter Stone, "Big Bill Broonzy," Association for Cultural Equity, accessed December 4, 2018, http://www.culturalequity.org/alan-lomax/friends/broonzy. Broonzy claimed to have recorded the song for Hugues Panassié in France in 1951 and reported that Alan Lomax and John Hammond pressured Mercury to record it in the United States. He performed it (badly, he was drunk) in Edinburgh in February 1952. Big Bill Broonzy, "Black, Brown, and White," Big Bill Broonzy, On Tour in Britain, 1952 (London: Jasmine Records JASMCD 3011/2, 2002). It was not popular with "Negro" listeners to begin with, complained Broonzy, because most of them were attempting to assimilate to white culture and did not want to be reminded that whatever they did, they would have to "get back." Big Bill Broonzy and Yannick Bruynoghe, Big Bill Blues (New York: De Capo Press, 1992), 83-5. Big Bill Broonzy, "Get Back (Black, Brown and White) 1945,” Black Brown and White (Mercury 842 743-2, 1991). "Color" songs are common in the blues and jazz archive, and Broonzy mentioned Louis Armstrong's recording of Fats Waller's “(Why Do I Have to Be So) Black and Blue," as an influence, but not Duke Ellington's contemporaneous jazz opera, "Black, Brown and Beige." Amiri Baraka (as LeRoi Jones) quoted part of the lyrics in Blues People: Negro Music in White America (New York: William Morrow and Company, 1963), 185. See also Kevin D. Greene, “Just a Dream': Big Bill Broonzy, the Blues, and Chicago's Black Metropolis,” Fournal of Urban History 40, no. 1 (2014): 116-36, https://doi.org/10.1177/0096144213489261.

${ }^{12}$ David Hesmondhalgh discusses fascinating instances of governments recuperating subaltern and proletarian music for nationalist purposes in Why Music Matters (Oxford: Wiley-Blackwell, 2013), 158-62. Broonzy's song is never installed officially as a sound of state.
} 
Structure of feeling and selective tradition have been examined, explicated, and invoked in the social sciences again and again over the last sixty years. ${ }^{13}$ Many now gesture to structure of feeling to point to elusive matters of affect, cathexis, mood, or atmosphere, without locating the concept theoretically. ${ }^{14}$ With Andrew Milner and John Clarke, ${ }^{15}$ I stress the Gramscian-Marxist framework of Williams's mature analysis, which has faded or disappeared from later invocations of the concepts. ${ }^{16} \mathrm{I}$ take seriously Williams's observation that, "methodologically . . 'structure of feeling' is a cultural hypothesis" that comes from attempts to understand the connections among living elements in a period in their "generative immediacy" without reducing them to an established form. The challenge that Williams poses to cultural analysis of politics is to recognize the active presence of "specific feelings and specific rhythms" and to recognize the "specific kinds of solidarity" that sustain them and that they express before they are fully formed. ${ }^{17}$ Being able to do so would guide socialist practice. I argue that while Williams articulates a political problem clearly, he does not resolve it satisfactorily-nor, in the nature of the case, can the resolution be found outside political practice.

\footnotetext{
${ }^{13}$ Beverley Best, "Raymond Williams and the Structure of Feeling of Reality TV," International fournal of Humanities and Social Science 2, no. 7 (2012): 192-201; Rebecca Coleman, "Theorizing the present: digital media, pre-emergence and infrastructures of feeling," Cultural Studies 32, no. 4 (2018): 600-22, https://doi.org/10.1080/09502386.2017.1413121; Paul Filmer, "Structures of feeling and socio-cultural formations: the significance of literature and experience to Raymond Williams's sociology of culture," British fournal of Sociology 54, no. 2 (2003): 199-219; Leonard Grossberg, "The cultural studies' crossroads blues," Cultural Studies 1, no. 1 (1998): 65-82; Jennifer Harding and E. Deidre Pribram, "The Power of Feeling: Locating Emotions in Culture," European Fournal of Cultural Studies 5, no. 4 (2002): 407-26, https://doi.org/10.1177/1364942002005004294; John Kirk, "Class, Community and 'Structures of Feeling' in Working-Class Writing from the 1980s," Literature E History 8, no. 2 (1999): 44-63, https://doi.org/10.7227/LH.8.2.4; David Simpson, "Raymond Williams: Feeling for Structures, Voicing 'History," Social Text 30 (1992): 9-26; Michalinos Zembylas, "'Structures of Feeling' in Curriculum and Teaching: Theorizing the Emotional Rules," Educational Theory 52, no. 2 (2002): 187-208, https://doi.org/10.1111/i.1741-5446.2002.00187.x.

14 "Structure of feeling" suffers the same fate as concepts such as "discourse," "soundscape," "the looping effect," or "technology of the self." See R. Keith Sawyer, "A Discourse on Discourse: An Archeological History of an Intellectual Concept," Cultural Studies 16, no. 3 (2002): 433-56; Ari Y. Kelman, "Rethinking the Soundscape," Senses and Society 5, no. 2 (2010): 212-34, https://doi.org/10.2752/174589210X12668381452845. A large number of works gesture to structure of feeling while removing its theoretical context. Jeffrey Alexander's print-media account of the Obama election, for instance, proposed that: "The civil sphere is more than legally guaranteed rights, private associations, and voluntary groups. It is also a structure of feeling. It is defined by the experience of solidarity, by a feeling of identity with, or at least empathy for, every other member of one's society." Alexander uses the Parsonian "societal community" as a synonym, pointing to solidarity, but removing the Gramscian frame. Jeffrey C. Alexander, The Performance of Politics: Obama's Victory and the Democratic Struggle for Power (New York: Oxford University Press, 2010), 9-10. Elsewhere, structure of feeling is a synonym for "mood," as in Isaac Reed and Jeffrey C. Alexander, "Social Science as Reading and Performance: A Cultural-Sociological Understanding of Epistemology," European fournal of Social Theory 12, no. 1 (2009): 21-41, at 24. Gestural uses of the concept suggest that it works as a sort of placeholder for an analytical problem space. Bruce Curtis, "How Much and How Not to Explain: Gestural Referencing and Conceptual Misappropriations," Canadian Fournal of Sociology/Cahiers canadiens de sociologie 40, no. 2 (2015): 223-40, https://doi.org/10.29173/cjs24993.

${ }^{15}$ John Clarke, "Subordinating the Social? Neo-liberalism and the remaking of welfare capitalism," Cultural Studies 21, no. 6 (2007): 974-87, https://doi.org/10.1080/09502380701470643. Andrew Milner, "Cultural Materialism, Culturalism and PostCulturalism: The Legacy of Raymond Williams," Theory Culture and Society 11 (1994): 43-73, https://doi.org/10.1177/026327694011001005. I do not endorse Milner's scornful disdain for Michel Foucault's work because his analysis of subjectification as political strategy offers a correction for Williams's seeming reliance on experience as the main source of subject formation. See the last two lectures in Michel Foucault, The Birth of Biopolitics: Lectures at the Collège de France, 1978-1979, trans. Graham Burchell (New York: Palgrave Macmillan, 2008.)

${ }^{16}$ Even more sustained and innovative engagements with Williams's concern to understand practical consciousness in the present underplay his class politics, as in Coleman's "Theorizing the Present," an intriguing analysis of cultural emergence and "infra-structures of feeling," or they stress his class politics, but attend little to the Gramscian problematic of hegemony, as in the account of "affective economies" in Jennifer Harding and E. Deidre Pribram, "The Power of Feeling: Locating Emotions in Culture," European Fournal of Cultural Studies 5, no. 4 (2002): 407-26.

${ }^{17}$ Raymond Williams, Marxism and Literature (New York: Oxford University Press, 1977): 132-3, my emphases.
} 


\section{Gramsci and Williams}

Raymond Williams drew on Antonio Gramsci's analysis of hegemony as part of a critique of the base/superstructure metaphor, which he undermined by insisting that capitalist production is always cultural production (and, under capitalism, vice versa). ${ }^{18}$ Williams argued that cultural forms were elements in a matrix, a totality of relations structured by bourgeois domination, but whose components were in complex relations of inter-determination. Hegemony is a continually problematic process in which groups and classes vying for political and economic dominance, in normal times, must direct, discipline, and educate subordinate groups and classes. Ruling groups must lead in order to govern successfully, and leading involves generating some measure of consent on the part of the ruled. Established cultural hegemony is "the substance and limit of common sense for most people under its sway," and "a sense of reality for most people in the society." If it succeeds, hegemony penetrates to the core of social subjects by organizing "our assignments of energy" (i.e., it is corporeal) and by establishing a set of mutual confirming beliefs about the reality of the world. ${ }^{19}$ Post-war communication technologies extended the reach of hegemonic practices more thoroughly into popular culture and everyday life than ever before. Counter-hegemonic practice would reorganize popular energies: music and dance are media of contestation for hegemonic and for counter-hegemonic strategies.

The unending struggle for hegemony, under changing technical and economic conditions of cultural production, encourages the emergence of new cultural forms and practices, both as extensions of the hegemonic and as reconfigurations or reinventions of the marginal. Hegemonic politics works to enlist consent by selectively valuing aspects of cultural production and experience as tradition, "that which, within the terms of an effective dominant culture, is always passed off as 'the tradition,' 'the significant past." These initiatives center on the incorporation of some alternative and some oppositional meanings and practices to the exclusion of others. "Some of these meanings and practices are reinterpreted, diluted, or put into forms which support or at least do not contradict other elements within the effective dominant culture." ${ }^{20}$ Yet oppositional cultural forms and practices live on under hegemony as residues, more or less marginalized, but inscribed in social memory. Since for Williams hegemony is a continual struggle for the legitimation of the fundamentally illegitimate, oppositional forms are continually re-emerging. They are propelled by changing means of communication, changes in material conditions and class structure, and

\footnotetext{
${ }^{18}$ Antonio Gramsci's influence in Britain followed the translation of The Modern Prince (London: Lawrence \& Wishart, 1957), extracts from his work on the state-as-educator, "In Search of the Educational Principle," New Left Review, no. 32 (1965): 5361, and its subsequent extension in Selections from the Prison Notebooks (London: Lawrence \& Wishart, 1973). His work aided the spread of socialist humanism, stimulated by opposition to the Soviet repression of Hungary and by the 1958 publication of Marx's Economic and Philosophic Manuscripts of 1844. People in Williams's circles saw Gramsci's work as authorizing the critique of orthodox Soviet Marxism, encouraging the rejection of economism, pointing to the need to create socialist intellectuals, and underlining the importance of the state-as-educator in a matrix of cultural-political relations. Early influential contributions were Christopher Hill, “Antonio Gramsci,” The New Reasoner, no. 4 (1958): 107-13, and Gwyn A. Williams, "The Concept of 'Egemonia' in the Thought of Antonio Gramsci: Some Notes on Interpretation," Fournal of the History of Ideas 21, no. 4 (Oct.-Dec.) (1960): 586-99, https://doi.org/10.2307/2708106. Both Raymond Williams and Stuart Hall took up versions of Gramsci's analysis in the early 1970s, if not before. See Raymond Williams, "Base and Superstructure in Marxist Cultural Theory," New Left Review, no. 82 (1973): 3-16; Problems in Materialism and Culture: Selected Essays (London: Verso, 1980); Stuart Hall, “The 'Political' and the 'Economic' in Marx's Theory of Classes," in Classes and Class Structure, ed. Alan Hunt, (London: Lawrence and Wishart, 1977), 15-60; "Re-thinking the 'Base-andSuperstructure' Metaphor," in The Communist University of London: Papers on Class, Hegemony and Party, eds. Jon Bloomfield, Dave Coutinho, Alan Hunt, and James Klugmann, (London: Lawrence and Wishart, 1977), 43-72. For the insight that production is cultural production, see Raymond Williams, Politics and Letters: Interviews with New Left Review (London: New Left Books, 1979), 143-5.

${ }^{19}$ Williams, Problems in Materialism and Culture, 37-8.

${ }^{20}$ Williams, Problems, 39.
} 
by the relatively autonomous development of cultural practice itself. Emergent cultural forms may draw upon existing cultural elements and present them in a new guise, employing new means of cultural production, or they may invent new modes of cultural production and communication in changing material conditions.

To understand the limits of cultural hegemony, Williams argues that we must distinguish "between residual-incorporated and residual not incorporated, and between emergent-incorporated and emergent not incorporated" cultural elements. It is relatively straightforward to identify both incorporated residual elements and those residual elements excluded from "tradition." Emergent-incorporated elements are more difficult, precisely because they are in the process of formation. ${ }^{21}$ But especially difficult is the identification of emergent, not incorporated elements. Williams puts the problem succinctly: "our hardest task, theoretically, is to find a non-metaphysical and non-subjectivist explanation of emergent cultural practice." 22 Again, the "major theoretical problem . . . is to distinguish between alternative and oppositional initiatives and contributions which are made within or against a specific hegemony ... and other kinds of initiative and contribution which are irreducible to the terms of the original or the adaptive hegemony, and are in that sense independent." ${ }^{23}$ Emergent oppositional cultural practice is what may undermine bourgeois hegemony.

Axiomatically, domination must exclude certain areas of cultural production from tradition; it can never accommodate the full range of human expressivity, precisely because it is domination. There is then a disjuncture and dissonance experienced by dominated groups and classes between the affordances of hegemonic culture (its selective tradition) and practical experience. Structure of feeling was Williams's attempt to theorize such dissonance, which "might very often be one of the social sources of art." 24 Structure of feeling is a deliberately contradictory concept, but "it was a structure in the sense that you could perceive it operating in one work after another which weren't otherwise connected ... yet it was one of feeling much more than of thought—a pattern of impulses, restraints, tones, for which the best evidence was often the actual conventions of literary or dramatic writing." 25 Again, structure of feeling is found in "characteristic elements of impulse, restraint, and tone; specifically affective elements of consciousness and relationships ... practical consciousness of a present kind, in a living and interrelated continuity." ${ }^{26}$ For the historian of literature and art, structure of feeling is relatively easily grasped in cultural products. As a method of analyzing literary texts, structure of feeling could be uncovered by attending to the characteristic conventions, tropes, and figures employed by writers working in a common

\footnotetext{
${ }^{21}$ In the case studied here, one can distinguish the shift in Broonzy's now very mild critique of racism from residual not incorporated to residual incorporated. The exclusion from the Obama campaign of the ribald, lascivious, and irreligious songs that occupy so much of the blues archive created residual not incorporated elements. An example of emergence and incorporation could be the attempts at the dilution of the raw energies of early 1950s rock and roll by polite, Christian remakes: e.g., Little Richard's “Tutti Frutti” as sanitized by the white Christian crooner Pat Boone. The commercialization and mainstreaming of hip hop is another instance.

${ }^{22}$ Williams, Problems, 41-2.

${ }^{23}$ Williams, Marxism and Literature, 114.

${ }^{24}$ Williams, Politics and Letters, 159. "Structure of feeling" appears in several parts of Williams's early work, but it is after his encounter with Gramsci that it acquires the meanings it has here.

${ }^{25}$ Williams, Politics and Letters, 159.

${ }^{26}$ Williams, Marxism and Literature, 132.
} 
period unbeknownst one to another, and here, Williams argued, was its most straightforward application. ${ }^{27}$

\section{What is the Next Thing?}

How is it possible to identify and to grasp emergent cultural forms and practices that have counterhegemonic potential before they are incorporated, eviscerated, or mobilized by reaction? Such is Williams's political-cultural problematic and ambition. Cultural production is always active, always in the present, and "what we have to observe is in effect a pre-emergence, active and pressing but not yet fully articulated, rather than the evident emergence which can be more confidently named." Such preemergence results, once again, from an always present "tension between the received interpretation and practical experience ... the tension is often an unease, a stress, a displacement, a latency." Pre-emergence (or pre-emergent cultural form?) "is a kind of feeling and thinking . . . in an embryonic phase before it can become fully articulate and defined exchange." More controversially, "emergent or pre-emergent" cultural forms and practices "do not have to await definition, classification, or rationalization before they exert palpable pressures and set effective limits on experience and on action."28

Relatedly, in Politics and Letters, Williams argued against claims that experience depends upon articulation. He insisted that dominant cultural forms and conventions work as blockages for the inarticulate experience of the dominated. Removing those blockages through practices that change the relations of signifier and signified could cause a shock of recognition that would certify a structure of feeling. Here structure of feeling would make itself visible as a reassignment of energy, a surge of energy and enthusiasm into an emerging cultural form. ${ }^{29}$ Funk, I suggest below, was just such a cultural form.

The post-1979 Thatcher government's brutal attacks on the material conditions and institutions of the British working class, and the reality of working-class Toryism, pushed Williams to reformulate his analysis of structure of feeling in ways that are also pertinent for the analysis of the Obama campaign. He moved away from presenting structure of feeling as the tension between a unified hegemonic culture and a lived, collective working-class experience. He argued that different social classes have different structures of feeling, while the development of digital media created new resources for diverse, potentially oppositional cultural forms. He stressed the ways in which hegemonic initiatives seek to "displace and divert our diverse actual confusions, pains and anxieties" through "systematic dislocations" and "powerfully funded alienation." His emphasis shifted somewhat from treating structure of feeling as an expressive phenomenon, towards a concern with political tactics that seek to evoke a structure of feeling and to contain it within hegemonic forms ${ }^{30}$ I argue that the Obama campaign did just this—but not as did Thatcher, Reagan, and Bush by dystopian appeals to the "free" individual against supposedly oppressive collectives, such as unions and the nanny state-rather, by imagining a utopian community of post-racial

\footnotetext{
${ }^{27}$ A particularly powerful demonstration by Williams is his contrast between the late eighteenth-early nineteenth-century "country house" novels (of Jane Austen, for instance), and the fiction of Charles Dickens. Given the rapid growth of industrial capitalist commodity production, the conventions employed by the former to portray the "knowable community" no longer offer an intelligible representation of social life. Dickens's endless lists of characters and objects parallel the growth of the statistical modes of representation, without which a world determined beyond immediate experience is mystifying. See Raymond Williams, The Country and the City (London: Chatto and Windus, 1973); Politics and Letters, 170-1.

${ }^{28}$ Williams, Marxism and Literature, 126-7; 131-2.

${ }^{29}$ Williams, Politics and Letters, 164-8.

${ }^{30}$ Raymond Williams, "The Uses of Cultural Theory" in The Politics of Modernism: Against the New Conformists, (London: Verso, 1989), 175-6. For a compelling portrayal of working-class Toryism, see Carolyn Steedman, Landscape for a Good Woman: A Story of Two Lives (London: Virago, 1986).
} 
solidarity. Yet despite pointing to fertile sites for the emergence of counter-hegemonic cultural forms, such as gossip, jokes, satire, and popular music-making, Williams offered no useful method for discovering the "pre-emergent" in the present before its articulation. ${ }^{31}$

In other words, having observed the characteristic changes associated with structure of feeling in past cultural production, and accepting the analysis of hegemony, one may hypothesize the existence of oppositional energies-feelings, inflections, intonations, ways of being in the body, and so on - that have social consequences without yet having acquired formal solidity. Because such energies have yet to find articulation, their hypothetical existence does seem to appeal to a metaphysics.

The solution to the methodological and ontological problem posed by Williams is to be found in political practice. The hypothesis of the existence of pre-emergent forms in a structure of feeling is to be tested through practical attempts to incite their articulation and to mobilize them. In keeping with Gramsci's position, ${ }^{32}$ hegemonic and counter-hegemonic practice contains educational dimensions: structure of feeling as a potentiality acquires form in practice. Such practice incites and gives direction to what is latent, in a process that is never finally resolved.

It is a commonplace of music studies that music-making is an important site for the creation and expression of solidarity, but Williams only exceptionally spoke directly to the politics of popular musicmaking. ${ }^{33}$ Nonetheless, his concepts are congenial to the study of music-making and politics. He made frequent appeals to "rhythm", "tempo," "tone," "timbre," "intonation," and cadence in speech to point to what is recognized and understood by members of a community prior to its explicit articulation. Such concepts are tied to modes of being in the body, and as we saw, for Williams hegemony is corporeal, concerning "our assignments of energy." As with music-making and dance, engagement with literature, theatre, and film can be a form of flow: all-encompassing corporeal immersion. ${ }^{34}$ Since Williams saw structure of feeling as a stylization of experience that varied across generations, he implicitly invoked shifting tempo, rhythm, and practices of citation: the intertextual nature of musical performance and products across time. ${ }^{35}$

Citation and intertextuality form part of the configuration of tradition through music. Web 2.0 altered the terrain of tradition-making through the technical possibilities offered by mash-ups, sampling, mixing, and overdubbing, at the same time as the ease and facility with which many actors can intervene in the process altered the conditions of possibility for leadership and domination.

\section{Music-making and Politics under Web 2.0}

The 2008 Obama campaign and Obama supporters made extensive use of the new possibilities that existed for the first time under web 2.0, especially through the creation and diffusion of playlists, the

\footnotetext{
${ }^{31}$ Raymond Williams, "Culture and Technology," in Politics of Modernism, 137.

${ }^{32}$ Antonio Gramsci, Selections from the Prison Notebooks (London: Lawrence \& Wishart, 1973), 247-60.

${ }^{33}$ On punk, see Raymond Williams, "Popular culture: history and theory," Cultural Studies 32, no. 6 (2018): 903-28, https://doi.org/10.1080/09502386.2018.1521620. By contrast, Stuart Hall raised the issue in relation to skiffle in some of his earliest publications, Stuart Hall, "The Politics of Adolescence," Universities and Left Review, no. 6 (1959): 2-4.

${ }^{34}$ On "flow," see Hesmondhalgh, Why Music Matters, 30-1. On reading as complete corporeal immersion, see Roger Chartier, "The practical impact of writing," in A History of Private Life, ed. Roger Chartier (Cambridge, MA: Harvard University Press, 1989), 111-65. Anne Danielson, in Presence and Pleasure: The Funk Grooves of James Brown and Parliament (Middletown, CT: Wesleyan University Press, 2006), 47, points to some similarities in the approaches of musicology and literary theory to rhythm: "In literary theory on rhythm, rhythm is also viewed as an interplay of actual events and virtual structures, the latter commonly referred to as meter."

${ }^{35}$ Williams, Problems in Materialism, 47.
} 
making of YouTube videos, and blog posts. While presidential election campaigns and inaugurations have always been more or less musical, the 2008 campaign was unusually so.

Web 2.0 changed the dynamics of US electoral politics dramatically. Obama campaign officials had a strong, relatively conventional ground game, ${ }^{36}$ but used sites such as BarackObama.com, Voteforchange.com, Facebook, Reddit and Twitter to contact potential voters directly and to create huge databases using every-person identifiers. The databases made it possible to map areas of voter support closely, to track polling results, to intensify fund-raising efforts, and to target campaign events, while maintaining contact and providing propaganda. The Obama campaign managed to minimize dependence on the "Super-Pacs" allowed under the US's distorted campaign finance law; it mobilized grassroots support, extending the candidate's image as a force for progressive change. ${ }^{37}$

While there were precedents in the 2004 Democratic campaign, Obama's online presence was pathbreaking. ${ }^{38}$ YouTube videos were especially important in the campaign. The organization itself produced a huge number of videos, perhaps 1,800 to the Republican effort's 300 and even inserted banner advertisements into a number of online video games. There were reportedly fifty full-time videographers working on a daily basis to post music videos tailored to particular demographic segments. Many people not formally part of the campaign participated. Particularly influential was Black Eyed Peas' will.i.am's "Yes We Can" video of Obama's concession speech after the January 2008 New Hampshire primary. Thirty-four musicians, actors, activists and other celebrities joined will.i.am to overdub the speech in a variety of formats and languages. There was no campaign involvement in the video, but it went viral after its February release, capturing as many as 21 million views by summer $2008 .^{39}$ There are far too many other instances of musical interventions for me (or, so far, for anyone else) to inventory, but overdubbing and sampling Obama speeches was a relatively common phenomenon. ${ }^{40}$

Other citizen and celebrity supporters mobilized many different genres of music, and the playlists selected to accompany campaign events and the official musical compendium offered for distribution and sale did so as well. Campaign events had the atmosphere of a combined rock concert and religious revival. The campaign's most popular playlist, later issued on CD as Yes We Can: Voices of a Grassroots Movement, touched many musical bases, from folk/roots, through Latin, Chicano rock, hip hop, funk and soul, and gospel, to R\&B, with gestures to the blues, country and country rock. A similar range of coverage was present in the CD Yes We Can! by Maria Muldaur and vocal accompanists (Bonnie Raitt, Joan Baez, Odetta, Phoebe Snow, Holly Near, and others) released early in 2008. The video accompanying the title

\footnotetext{
${ }^{36}$ Alexander, Performance of Politics.

${ }^{37}$ Carpenter, "The Obamachine"; Cogburn and Espinoza-Vasquez, "From Networked Nominee."

${ }^{38}$ The strong sense that politics was on the cusp of radical, far-reaching, and as yet obscure changes impressed Michelle Obama. See Michelle Obama, Becoming (New York: Crown, 2018), 252: "We were standing on the edge of something I'm not sure any of us yet fully understood."

${ }^{39}$ For an incisive analysis of this video and of such media in the campaign more generally, see Carol Vernallis, "Audiovisual Change: Viral Web Media and the Obama Campaign," Cinema fournal 50, no. 4 (2011): 73-97, https://doi.org/10.1353/cj.2011.0062; for a larger view, see Daniel Blim, “The Electoral Collage: Mapping Barack Obama's Mediated Identities in the 2008 Election," in "Patchwork Nation: Collage, Music, and American Identity" (Ph.D. diss., University of Michigan, 2013); Kevin Wallsten, “Yes We Can': How Online Viewership, Blog Discussion, Campaign Statements, and Mainstream Media Coverage Produced a Viral Video Phenomenon," Fournal of Information Technology $\mathcal{E}$ Politics 7, no. 2-3 (2010): 163-81, https://doi.org/10.1080/19331681003749030. For a list of the performers who participated, see "Wikipedia: Yes We Can (will.i.am Song)," Wikimedia Foundation, last modified September 18, 2019, https://en.wikipedia.org/wiki/Yes_We_Can_will.i.am_song). The video is accessible at https://www.youtube.com/watch?v=ijXyqcx-mYY. It quickly went viral.

${ }^{40}$ One final example is the former Eurhythmics front man Dave Stewart's American Prayer dubbed over an Obama campaign speech, https://www.youtube.com/watch? $=0$ Vi4rUzf-0Q (accessed December 12, 2018).
} 
track cast Obama firmly in the lineage of such heroes of the Civil Rights movement as Rosa Parks and Martin Luther King Jr. ${ }^{41}$

Barack Obama's own musical tastes were a matter of cultural-political interest, as individuals and groups tried to place him musically, treating his preferences in music as related to his political project. Thus much contemporary discussion focused on Obama's relations to hip hop and rap, from his censure of misogynist lyrics and outlaw masculinities, to his embrace of those genres as expressions of black musical creativity. As Travis Gosa argues, Obama's influence briefly encouraged a political trend within rap composition, and the candidate attacked the misogyny and violence of gangsta rap directly. ${ }^{42}$ From Williams's point of view, in refashioning hegemony in the direction of cosmopolitan and post-racial capitalism, the campaign needed to draw upon but also to tame the oppositional energies of African American music. The rage and oppositional thrust of some religious energies were also blunted. ${ }^{43}$

For all the importance of the debate over hip hop, Barack Obama and Michelle Robinson Obama were teenagers and young adults in the 1970s and 1980s, as R\&B morphed into new styles of gospel music, into soul and funk and, briefly, disco. ${ }^{44}$ Commentators noted that hip hop was the music of the generation after Obama came of age, and that his own somewhat eclectic musical tastes were most concentrated on the genres of soul and funk. ${ }^{45}$ The political campaign's playlists were heavily weighted towards these musical trends, whose appeal was to a broad cross section of African American voters, but which had long since crossed over to white audiences as well. Many compositions had a wide commercial presence in film and advertising. ${ }^{46}$

The campaign's fashioning of a broad political coalition was inextricably bound up with the fashioning of a broad musical coalition, and musicians who supported Obama's candidacy themselves outlined a collective musical space.

\section{Selections and Selective Amnesia}

The placement of the candidate as the inheritor of peaceful protest for civil rights, of moral uplift, religious fidelity and monogamous respectability, as well as his repeated insistence upon individual moral responsibility, excluded or marginalized histories of rage, of violence, profanity, irreligion, lasciviousness,

\footnotetext{
${ }^{41}$ https://www.youtube.com/watch?v=ZLVXxGMG3Fw (accessed November 31, 2018). Muldaur changed Toussaint's "Now is the time for all good men ..." to "Now is the time for all mankind ...." and ended with "Si se puede."

${ }^{42}$ Travis L. Gosa, "Not Another Remix: How Obama Became the First Hip-Hop President," Fournal of Popular Music Studies 22, no. 4 (2010): 389-415, https://doi.org/10.1111/i.1533-1598.2010.01252.x; Travis L. Gosa and Erik Nielson, eds., The Hip Hop E Obama Reader (New York: Oxford University Press, 2015); and Gorzelany-Mostak, “Keepin’ It Real,” https://doi.org/10.1093/acprof:oso/9780199341801.001.0001.

${ }^{43}$ David A. Frank, "Obama's Rhetorical Signature: Cosmopolitan Civil Religion in the Presidential Inaugural Address, January 20, 2009," Rhetoric and Public Affairs 14, no. 4 (2011): 650-30, https://doi.org/10.1353/rap.2011.0044; Jakobsen and Pellegrini, “Obama’s Neo-New Deal.”

${ }^{44}$ Michelle Obama's first record was Stevie Wonder's 1972 Talking Book, almost entirely full of love songs, including the mega-hit "You Are the Sunshine of My Life." Obama wrote that she found much in common with her future husband in music: "We debated the merits of every single Stevie Wonder album before doing the same thing with Marvin Gaye." Obama, Becoming, 113. She "wore out" Motown records as a teen, The New Zealand Herald, February 12, 2019. Wonder's Talking Book contained one forceful political song, "Big Brother," to that date out of character for Wonder, which ends with an address to political candidates: "We live in the house the size of a matchbox / We just live with this war to war / You've killed all our leaders, / I don't even have to do nothin' to you, / You'll cause your own country to fall." The Yes We Can CD included Wonder's love song "Signed, Sealed, Delivered I'm Yours," but none of his political songs. See James E. Perone, The Sound of Stevie Wonder: His Words and Music (Westport, CT: Praeger, 2006).

${ }^{45}$ Gorzelany-Mostak and Deaville, "On the Campaign Trail(er)."

${ }^{46}$ Gorzelany-Mostak, "Keeping it Real," 128, gives a typical campaign event playlist.
} 
blasphemy, and of the ribaldry that feature prominently in some genres of African American musical production, such as blues and rap. Obama's critique of some and embrace of other versions of hip hop can be read as a strategy for the defanging of potentially emergent-oppositional cultural practice. As Kristen Hoerl demonstrates, the mainstream media's portrayals of Obama fashioned a selective amnesia about other lineages of African American political struggle, forgetting the Black Panthers and Black Power, and figuring a Martin Luther King, Jr. before his anti-Vietnam, anti-imperialist stances and his move towards democratic socialism. ${ }^{47}$

Dana Gorzelany-Mostak's analysis of the campaign's configuration of the musical field demonstrates the predominance of cross-over songs of love, hope, caring, and redemption. Obama, she argues, "appropriate[d] the political tropes and rhetorical strategies of his black political forebears to carve out his own legitimacy and respectability." She continues, "the sonic qualities of the songs that tell the stories not only signify blackness, but also more specifically, embody a style of black music associated with racial uplift, mainstream tastes, and middle-class respectability." 48

\section{"Yes We Can Can"}

Of course, the Obama campaign's musical selections were musical exclusions, the creation of selective tradition, whose elements were meant to energize and to evoke affective solidarity on the part of listeners and dancers. The campaign strategy involved refiguring the structure of feeling-the tensions, dissonances, anxieties, struggles, and hatreds-provoked by the George W. Bush regime through the rhythms of interpersonal love and of yearning for a better world. Very few, if any, of the explicitly political songs prominent in 1960s and 1970s funk and soul were enlisted in this effort (despite the presence of Stevie Wonder at almost every rally).

The genealogy of the slogan and campaign chant "Yes We Can" is particularly interesting in this regard, as an indication of what was excluded and as a site for analyzing counter-hegemonic potentials. Before Obama's 2004 Senate campaign, where it was first used, there were two other instances of "Yes We Can," both in the 1970s. ${ }^{49}$ One, as "si se puede" is attributed to Cesar Chavez of the United Farm Workers during his 1972 hunger strike against anti-union legislation. Through the efforts of his comrade, Dolores

\footnotetext{
${ }^{47}$ Kristen Hoerl, "Selective Amnesia and Racial Transcendence in News Coverage of President Obama's Inauguration," Quarterly Fournal of Speech 98, no. 2 (2012): 178-202, https://doi.org/10.1080/00335630.2012.663499.

${ }^{48}$ Gorzelany-Mostak, "Keeping it Real," 140; James B. Stewart, "Message in the Music: Political Commentary in Black Popular Music from Rhythm and Blues to Early Hip Hop," The Fournal of African American History 90, no. 3 (2005): 196-225, https://doi.org/10.1086/JAAHv90n3p196, points out that Motown and other studios were commonly recording songs by black artists with a view to their accessibility for white cover artists.

49 The precise origins of the campaign slogan must remain obscure. The 2004 senate campaign manager, David Axelrod, is credited with first suggesting it to Barack Obama, who reportedly found it corny at first hearing. It was Michelle Obama's support that was decisive for the slogan's adoption. Years later, Barack Obama would attribute it, jokingly, to Dolores Huerta. "Si se puede" translates not to "yes we can," however, but to "yes it can" or in its original context, to "yes it can be done." On the other hand, Michelle Obama was enduringly influenced by her childhood and adolescent exposure to Motown recordings-for instance, choosing a song from Stevie Wonder's Talking Book album, the first record she owned, as the theme song for her wedding (Obama, Becoming, 164). It is hard to imagine that she did not hear the Pointer Sisters' 1973 version of "Yes We Can Can," a major hit that charted at no. 11 on the Billboard Hot 100 and at no. 12 on the R\&B list. Axelrod's phrase likely had some resonance with her in consequence. While it would be elegant to be able to say that Toussaint's "Yes We Can Can" directly inspired the slogan, analytically it does not matter: if the song did not produce the slogan, the adoption of the slogan generated more exposure for the song, and the song contains much of the campaign message. In any case, a genealogical analysis does not demand linear descent. See Katie Mettler, “Obama's 'yes we can' almost didn't happen. You can thank Michelle for saving it," The Washington Post, January 11, 2017, https://www.washingtonpost.com/news/morningmix/wp/2017/01/11/obamas-yes-we-can-thank-michelle-for-that/, for more background on the adoption of the slogan for the 2004 senatorial campaign.
} 
Huerta, this slogan became a global movement standard. (Obama awarded Huerta the Presidential Medal of Freedom in $2012 .^{50}$ ) The other version was Allen Toussaint's 1970 funk composition, "Yes We Can Can." Some performances of Toussaint's song repeated the Chavez slogan. (Obama awarded Toussaint a National Medal of the Arts for 2012. ${ }^{51}$ )

Through his extraordinary talent as a composer, arranger, producer, session musician, and later, performer and recording artist with a massive repertoire, New Orleans's Allen Toussaint (1938-2015) made an important mark on American musical culture over sixty years. His oeuvre as a whole is inextricably bound up with the elevation and gentrification of African American jazz and blues and their descendants, their solidification in mainstream culture and hence their availability as political resources. ${ }^{52}$ He played a significant role in the emergence of funk, whose development can itself be seen to certify a changing structure of feeling, both as a surge of energy into a new cultural form and, as I show below, as a shift in the presence and substance of language.

By virtue of its location as the main ocean port between the United States and the Caribbean, its heritage of French, Spanish, and West African musical practices, its large Creole population, and a long history of marching bands, New Orleans possessed a unique musical palette and sonic ecology. The city's bands were typically trailed or paralleled by a "second line" of dancers and percussionists playing all kinds of instruments and objects alongside, over or against the band's syncopations. Such "additive rhythms," alien to Western art music, embodied musical experiences that were both participatory and layered.

Alexander Stewart argues that the larger framework of the emergence of funk involved related shifts away from swing rhythms in jazz and jump blues towards the predominance of straight or even eighths in rock and roll by the 1960s, along with the rise of separate dancing. Many rock and roll and R\&B artists from the early 1950s were playing a mixture of shuffle and straight rhythms, but only in New Orleans did such mixtures become a definitive characteristic. Some of Fats Domino's early recordings, such as "I'm Walkin'," were influential, and Toussaint frequently sat in for Domino when the latter was traveling. The rhythmic mix created startling new sensations, called "in-between-ness" by some, and brilliantly illustrated by Stewart with Paul Gayton's "Nervous Boogie" (1957)..$^{53}$

Benjamin Doleac writes that the shift to a mix of straight and shuffle rhythms "opened up a space for New Orleans musicians to experiment further with the mixed feel of the second line." He underlines the important role played by Allen Toussaint's teacher/mentor Professor Longhair (see below) from the end of the 1940s in incorporating "additive Afro-Caribbean rhythms and layered straight beats against swung beats to create a new R\&B piano style known as the 'piano rumba." As producer and pianist, "Allen Toussaint ... added second line brass band arrangements" to the hits of such artists as Fats Domino. ${ }^{54}$

Music historians point to the crucial role played by James Brown in the emergence and elaboration

\footnotetext{
${ }^{50}$ See "2011 Medal of Freedom Recipient Dolores Huerta," National Archives and Records Administration, May 12, 2012, https://obamawhitehouse.archives.gov/realitycheck/photos-and-video/video/2012/05/31/2011-medal-freedom-recipientdolores-huerta?tid=9.

${ }^{51}$ See "President Obama Awards the National Medal of Arts to Allen Toussaint," National Archives and Records Administration, July 2013, https://obamawhitehouse.archives.gov/photos-and-video/photo/2013/07/president-obamaawards-national-medal-arts-allen-toussaint.

${ }^{52}$ In this Toussaint had many predecessors, notably W.C. Handy, who translated black proletarian music into Western musical forms and notation; see W.C. Handy, Father of the Blues: An Autobiography (New York: Macmillan, 1970 [1941]).

${ }^{53}$ Alexander Stewart, "'Funky Drummer': New Orleans, James Brown and the Rhythmic Transformation of American Popular Music," Popular Music 19, no. 3 (2000): 293-318, https://doi.org/10.1017/S0261143000000180.

${ }^{54}$ Benjamin Doleac, "Strictly Second Line: Funk, Jazz, and the New Orleans Beat,” Ethnomusicology Review 18 (2013): 9.
} 
of funk as a genre and its spread on a national scale. ${ }^{55}$ Especially through his drummer, Clayton Fillyau, Brown picked up the street rhythms of New Orleans and used a constant emphasis on "the One" as the means to tie complex additive rhythms together. Fillyau reportedly hated playing shuffle and wanted to play "rhythms against rhythms." Stewart comments, "Musicians and listeners perceived African qualities and, especially during an era of rising black nationalism, the intricate, more 'in-your-face' style of drumming easily became identified as a funky celebratory march of ethnic difference." ${ }^{26}$

For his part, Tony Bolden insists on the significance of the funk genre as dance, both for James Brown and for those who participated in a funk groove. Brown danced his music, directing his band by more or less subtle gestures and bodily movements: a particular kind of kinetic communication. Funk by this account is a kinetic art and, while Bolden insists on its political substance, that substance comes from movement rather than from sound. The insistent groove produced by the groundwork of "the One" and complex polyrhythms that play with it create a music that incites movement on the part of listeners; that encourages people to "get up and dance." "The One" provides a point of reference, a principle of intelligibility, and grounds for kinetic solidarity. As such, in Williams's terms, it points to a shifting structure of feeling, as a surge of energy into a new cultural form.

Toussaint's work was influential in the emergence of a smooth variety of funk from the mid-1960s. Perhaps more significant than his influence as composer and lyricist were his multiple roles as producer, arranger, session player and partner in Sansu Records. The house band for Sansu was the New Orleans funk ensemble the Meters, who played on much of the funk and $R \& B$ that came out of the city from the band's formation in 1965, including Lee Dorsey's original recording of "Yes We Can Can." The band's drummer, Zigaboo Modeliste, created especially intriguing grooves.

"Yes We Can Can" was a contribution to the Black Pride movement at a moment when violent state repression of the Marxist Black Panther Party was underway. ${ }^{58}$ While the Panthers certainly supported black uplift, they did so by counter-organizing in inner city neighborhoods and by attacking racist and capitalist exploitation in the name of Black Power. They also sought to change the terms of debate, in part through the kinds of revaluations of language and of speech acts that Williams insisted are essentially political. ${ }^{59}$

\footnotetext{
${ }^{55}$ Danielson, Presence and Pleasure, provides a particularly incisive analysis of how groove works in funk. Much of the literature focuses on the roles of male musicians in funk, although E. Taylor Atkins, "The Funky Divas Talk Back: Dialogues about Black Feminism, Masculinity, and Soul Power in the Music of James Brown," Popular Music and Society 38, no. 3 (2015): 337-54, does point to the contributions of female members of Brown's bands. For some other ways in which female musicians have shaped and extended the genre, see Tammy L. Kernodle, "Diggin' You Like Those Ol' Soul Records: Meshell Ndegeocello and the Expanding Definition of Funk in Postsoul America," American Studies 52, no. 4 (2013): 181-204; and Matthew Valnes, "Janelle Monáe and Afro-Sonic Feminist Funk," Fournal of Popular Music Studies 29 (2017): 1-12, https://doi.org/10.1111/ipms.12224.. In his "Taking it higher: the spirituality of sensuality in funk performance," African and Black Diaspora: An International Fournal 9, no. 1 (2016): 3-15, https://doi.org/10.1080/17528631.2015.1055654, Valnes also contests the separation of the sexual from the spiritual in analyses of funk and undermines the sacred/profane binary. ${ }^{56}$ Stewart, "Funky Drummer," 304. Smith, The One.

${ }^{57}$ Tony Bolden, "Groove Theory: A Vamp on the Epistemology of Funk," American Studies 52, no. 4 (2013), https://doi.org/10.1353/ams.2013.0114: 9-34.

${ }_{58}$ Amy Abugo Ongiri, Spectacular Blackness: The Cultural Politics of the Black Power Movement and the Search for a Black Aesthetic (Charlottesville: University of Virginia Press, 2010); Reiland Rabaka, Hip Hop's Amnesia: From Blues and the Black Women's Club Movement to Rap and the Hip Hop Movement (Lanham, MD: Lexington Books, 2012); Rickey Vincent, Party Music: The Inside Story of the Black Panthers'Band and How Black Power Transformed Soul Music (Chicago: Lawrence Hill Books, 2013).

59 The most visible instance was Huey P. Newton's demand that the Party cease using "faggot" and "punk" to refer to homosexuals. Amy Abugo Ongiri, "Prisoner of Love: Affiliation, Sexuality, and the Black Panther Party," The Fournal of African American History 94, no. 1 (2009): 69-86, https://doi.org/10.1086/JAAHv94n1p69; Huey P. Newton, “The Women's Liberation and Gay Liberation Movements," in The Huey P. Newton Reader, eds. David Hilliard and Donald Weise, (New York: Seven Stories Press, 2002 [1970]), 157-9.
} 
In a complex relation to the repression of the Panthers, the assassinations of Martin Luther King and Robert Kennedy, and more besides, a strain of African American popular music increasingly promoted uplift as a matter of individual conduct, as the defiant message of James Brown's "Say It Loud" and Aretha Franklin's demand for "Respect" tussled with the Staple Singers' "Respect Yourself." Leading artists could record songs with radical messages with greater or lesser success, but record companies refused much political material. ${ }^{61}$ Allen Toussaint's rare musical social commentary sometimes spoke to economic inequality and the interior pain inflicted by racism, but typically denounced pimping, leaving school, irregular presence at work, ignorance, and false extravagance in the black community, standard themes of uplift. ${ }^{62}$ As in Obama's speeches, individual responsibility was a strong element in Toussaint's late 1960searly 1970s compositions.

With its danceable funky introduction and breaks, "Yes We Can Can" addressed a male African American listener and counseled him about interpersonal harmony, self-reflection, and collective selfhelp: ${ }^{63}$

Now's the time for all good men to get together with one another.

Iron out their problems and iron out their quarrels

And try to live as brothers.

And try to find the peace within without stepping on one another.

And do respect the women of the world.

Just remember we all had mothers

Chorus

Make this land a better land than the one in which we live.

And help each man be a better man with the kindness that we give.

I know we can make it, I know darn well we can work it out

Oh yes we can, I know we can can oh yes we can can, etc....

Take care of the children, the children of the world.

They're our strongest hope for the future, the little bitty boys and girls.

Chorus $^{64}$

Missing from its generic calls for masculine solidarity, respect for women as mothers (not sisters or lovers) and children is any direct critical documentation of or commentary on political economic conditions. By implication, black men are fighting with one another, mistreating women, and neglecting children: a stereotypical class-based critique of (black and Latino) proletarian life that cut across political factions. The

\footnotetext{
${ }^{60}$ J.S. Smith, The One: The Life and Music of Fames Brown (New York: Gotham Books, 2012), 208-10, recounts the Oakland Panthers' critique of James Brown for his processed hair; Brown's adoption of an Afro, and the coincident composition of "Say It Loud." Staples counsels obedience to employers and making do on whatever wages one might earn.

${ }^{61}$ Stewart, "Message in the Music," discusses a large number of such recordings. The music of J. B. Lenoir (1929-1967) is an example of repressed compositions. Lenoir came under political pressure for the first wave of his recordings in the early 1950s criticizing Eisenhower and the Korean War. His haunting comments on the civil rights struggle, such as "Shot on James Meredith" and "Alabama March," got little play. For a complete discography, see Stefan Wirz, "Illustrated J. B. Lenoir discography," accessed January 12, 2019, https://www.wirz.de/music/lenoir.htm.

${ }^{62}$ On his Yes We Can album, Lee Dorsey also recorded Toussaint's "Who's Gonna Help Brother Get Further." The lyrics are not quite as quietist as "Pops" Staples's 1973 "Be What You Are," but it is in the same field.

${ }^{63}$ In James B. Stewart's typology of political messages in R\&B music, the song joins elements of "All God's Children,"

"Awareness Raising Self-Criticism," and "Collective Self-Help Solutions." Stewart, "Message in the Music."

${ }^{64}$ My transcription; see https://www.youtube.com/watch?v=e4AWOmz53R4. In Danielson's terms, the piece seems to be in both "song" and "groove" modes; Presence and Pleasure, 148.
} 
lyrics contend that these men should examine their lives, seek strength from within, and care for mothers and children in order to make a better world-whatever its political economy might happen to be. With its danceable groove, "Yes We Can Can" was an ideal vehicle for the Obama campaign's generic calls for "hope," "change," and so on: a relatively empty feel-good signifier that could be invested with a variety of meanings. The song had wide cultural currency. Before the 2008 campaign, in addition to Lee Dorsey's 1970 recording, it had been covered by artists in genres including Latino/folk, R\&B, reggae, glam-rock, "Bayou Soul," and white-boy jazz, had been sampled, and was part of the soundtrack of the film The Associate. ${ }^{65}$

More striking is that, at least in the cross-over music of this period, "funk" and "funky" lost their negative connotations of the foul odor caused by sexually transmitted disease, or by the lack of personal hygiene on the part of women involved in pleasure commerce. ${ }^{66}$ Indeed, personal and sexual hygiene was a common, thinly-coded theme in blues recordings in the period before WWII. Established black urban residents chastised recent migrants for their lack of couth. White-sponsored projects of moral uplift of the "Negro," through journals such as The Journal of Negro Hygiene and organizations such as Chicago's American Social Hygiene Association, targeted (real or imagined) bodily habits. ${ }^{67}$ Commentary and advice on hygiene figured in the popular insult games known as "the dozens." 68

Earlier, in his unvarnished version of "Buddy Bolden's Blues," Jelly Roll Morton sang:

I thought I heard Bolden play,

Dirty nasty stinkin' butt, take it away,

A funky butt, stinky butt, take away,

And let Mister Bolden play. ${ }^{69}$

This song, current in New Orleans in the first decades of the twentieth century (and adapted from the earlier ragtime composition, "The St. Louis Tickle"), spread widely and with it the meaning of funk as bodily filth. In the early 1960s blues revival, the word retained such connotations. Mississippi John Hurt, for instance, in 1964 recordings for the Library of Congress, recorded "Funky Butt" in its earlier meaning:

See that girl with the blue dress on

She's got stinky butt, funky butt, leave it alone

'Cause I don't like it no how. ${ }^{70}$

Again, in the Texas barrelhouse piano standard, "Whores is Funky," Robert Shaw claimed:

\footnotetext{
${ }^{65}$ See "Yes We Can," Second Hand Songs, accessed November 30, 2018, https://secondhandsongs.com/work/56069/versions. ${ }^{66}$ In his essay "The Funk Aesthetic in African American Poetry" in Black Music, Black Poetry: Blues and Fazz's Impact on African American Versification (New York: Routledge, 2014), 79-90, Tony Bolden invokes Central African usage in the etymology of "funk." As lu-funki and $l u$-fuki, the term implies sweat and odor, but also honest toil and hence honor. The English etymology refers rather to foul odors and to ill-humor. Amiri Baraka observed that funky was invoked as a descriptor in hard-bop in jazz in the 1950s, but stressed that for many black people it continued to be impolite and to refer to the odor of sex. Blues People, 217-20.

${ }^{67}$ William Howland Kenney, Chicago fazz: A Cultural History, 1904-1930 (New York: Oxford University Press, 1993$), 37$.

${ }^{68}$ Elijah Wald, The Dozens: A History of Rap's Mama (New York: Oxford University Press, 2012). Charley Jordan's “Keep It Clean" (Vocalion 1511, 1930) was one of the best-known compositions, but the theme is visible in "hokum" songs such as "Keep Your Yes Ma'am Clean" by Sweet Papa Tadpole (Vocalion 1687, 1930), and "slut-shaming" songs in the "dozens" genre, such as "You Can’t Give It Away” by Memphis Minnie (Decca 7048, 1935). Sleepy John Estes challenged hygiene uplift projects in his "Clean Up at Home," (Decca 7516, 1938). See also Mary S. Hoffschwelle, “Better Homes on Better Farms': Domestic Reform in Rural Tennessee,” Frontiers: A Fournal of Women Studies 22, no. 1 (2001): 51-73, https://doi.org/10.1353/fro.2001.0008.

${ }^{69}$ Jelly Roll Morton, Complete Library of Congress Sessions, (Rounder Records, 2005), 1658A, Track 11.

70 “Mississippi” John Hurt, “Funky Butt,” D.C. Blues: The Library of Congress Recordings, Vol. 1 (Fuel 302061407 2, 2000 ), Track 2-3.
} 
I ain't gonna do it to you no more

The last time I did it you made my peepee sore

Oh, whores is funky ... ${ }^{71}$

As is typical in blues performance, Shaw's relation to funk is doubled: he continually extolls his female referent, repeating, "Yes, she's got it! Ain't nobody got it like she's got it!," laments catching a sexually transmitted disease, but ends by lauding her charms again and imitating orgasm.

The funk movement retained resonances of this earlier political/cultural/personal matrix, but embraced it wholeheartedly as a transgressive sense of cool. As Rickey Vincent quotes Alfred Pasteur and Ivory L. Toldson, "we could say that 'funk' rests at the root and stem of popular culture in America. From beneath the arms, the crotch, a sensually fragrant, musky perfume has arisen, activating an affective force that provides for life, enjoyment, enrichment and regeneration." 72

Toussaint's compositions were significant, if usually polite, contributions. "Everything I Do Gonh Be Funky" proclaims the singer's determination to express internal liberty and to be unperturbed by claims by others of a lack of "class": "Never before have I felt so good, just bein' a natural me. ..." Again, "Smooth Operator" is smoothly suggestive of the high status of pimping, without invoking the word. More striking is "Let's Get Low Down" (1966), composed by Toussaint and Curly Bridges, with its injunction

Baby get filthy, filthy as you can

Oh, get filthy baby, filthy as you can

'Cause it ain't no $\sin ^{73}$

Toussaint influenced the formation of funk lexically as well as rhythmically, and the two dimensions are in a complex relation. I argue that there is a process of gentrification, of defanging, involved. An element of African American self-affirmation is accompanied by a whiff of transgression in a danceable musical genre. Funk releases and co-ordinates bodily energies. Its counter-hegemonic potential is ambiguous: in so far as it involves a changed relation of signification, the genre may be seen to push against both the linguistic denigration of sexually active women that was ensconced in hegemonic discourses of the post-WWI period and to turn white supremacist discourses about malodorous black bodies into statements of pride. ${ }^{74}$ As such, for Williams, it points to a changing structure of feeling: it involves "characteristic elements of impulse, restraint, and tone," and a changed relation between signifier and signified. On the other hand, in Toussaint's versions at least, pleasure commerce and the economic-sexual power of black women, so central to blues and jazz composition and performance in the early decades of the twentieth century, are absent. And if funk represented an emergent-oppositional form in its early history, it was subject to incorporation.

\footnotetext{
${ }^{71}$ Robert Shaw, "Whores is Funky," on The Ma Grinder (Texas Barrelhouse Piano) (Arhoolie CD-377, 1962). The cultural/political distance traveled is quite dramatic: Kim Severon's New York Times food column, "The Spiral-cut ham-a cut above" (reprinted in the Toronto Star, April 12, 2019, E10), comments, "If an aged country ham is like jazz, funky and improvised, a spiral-cut is the pop music of the ham world. .."

${ }^{72}$ Rickey Vincent, Funk: The Music, the People and the Rhythm of the One (New York: St. Martin's 1996), 6.

${ }^{73}$ Recorded as Curly Moore, "Get Low Down, Part 1," (Sansu Records 457, 1966).

${ }^{74}$ Keire, For Business and Pleasure; "Swearing Allegiance." Amiri Baraka (LeRoi Jones) argued that the proud invocation of "funk" in jazz was a political counter to white supremacist claims that "Negroes" stank; see Blues People, 217-24, and writers on the development of funk cite players who describe their music as "stanky." Much earlier, the sociologist Georg Simmel argued that the distaste of the dominant classes for the smell of proletarian bodies made socialist solidarity impossible: the political question was a "Nasenfrage" (a nosey question). See Bruce Curtis, "I can tell by the way you smell': Dietetics, Smell, Social Theory," The Senses and Society 3, no. 1 (2008): 5-22, https://doi.org/10.2752/174589308X266434.
} 
A longer sketch of Toussaint's musical formation, his citation practices and the lineage in which he is situated points to the wider context from which he made selections and exclusions: to the raw subaltern energies he domesticated. The Obama campaign's core messaging and imaging mobilized such domesticated musical energies.

Alongside his active participation in the late 1950s and 1960s New Orleans rock and roll scene, Toussaint commonly pointed to the musicians Henry Roeland Byrd (1918-1980, "Fess," "Professor Longhair") and Isidore "Tuts" Washington (1907-1984) as his major influences. Washington mentored Byrd and these two figures connect Toussaint to the New Orleans jazz scene in its formative period. In his last two albums, The Bright Mississippi and American Tunes, Toussaint covered work he considered among the best or most representative of New Orleans's contributions: work by Byrd, but also by Sidney Bechet, Joe Oliver, Clarence Williams, and Jelly Roll Morton, musicians active in the first decades of the twentieth century. These musicians began their work in the city's red-light district, Storyville (18971917), and worked in brothels, clubs and cabarets after the district officially closed, or moved to similar settings in Chicago, Los Angeles, and New York. ${ }^{75}$

Tuts Washington learned to play piano as a very young child by listening to pianists in Storyville's brothels and spent the bulk of his musical career working in area clubs and cabarets. Washington spoke of Jelly Roll Morton's influence and covered Morton's "Wolverine Blues" in one of his rare recordings. While his repertoire demonstrates influences from pianists such as Chicago's Jimmy Yancey ("Yancey Special"), from those in Dallas ("Hattie Rogers Blues"), and in New Orleans itself ("Tipitina"), he was known for his bawdy lyrics as well, as in his own "Papa Yellow Blues." Morton, Washington, and Byrd influenced others in Toussaint's circles, among them Huey "Piano" Smith and James Booker, ${ }^{77}$ whose repertoire also contained bawdy material.

Excluded from Toussaint's citations and from Obama's later use of them is the ribald nature of compositions in this musical field. Excluded as well are almost all traces of the rough culture of prostitution, drugs, bootlegging, gambling, and violence in which blues and jazz were formed in New Orleans and other cities. Toussaint's elegant cover of Morton's "Winin' Boy Blues," for instance, is an instrumental, lacking Morton's relatively sanitized recorded lyrics from 1939 and containing no hint of the

\footnotetext{
75 Thomas Brothers, Louis Armstrong's New Orleans (New York: W. W. Norton \& Company, 2006); William Kenney, Chicago Fazz (Oxford: Oxford University Press, 1993); Bruce Boyd Raeburn, "The Storyville Exodus Revisited, or Why Louis Armstrong Didn't Leave in November 1917, Like the Movie Said He Did," The Southern Quarterly 52, no. 2 (2015): 10-33.

76 "Tuts" was short for tootsie roll, like jelly roll, a reference to the sex organ. "Papa Yellow Blues," on New Orleans Piano Professor (Rounder CD 11501, 1983) reads in part:
}

She's got great big legs,

But oh what noble thighs $\mathrm{x} 2$

She's got a little bitty something

Sights like a bull dog's eye

Roll me with your belly

Seize me with your toes $\mathrm{x} 2$

Throw your big legs off me

And squeeze me till I come

The first verse is part of a standard blues panegyric for the clitoris, often sung by men, (in Algernon "Texas" Alexander's 1928 "Boe Hog Blues": "She's got somethin' over yonder, works like a boe hog's eye," (OK 8563); also, Charley Jordan, “Twee Twee Twa," Decca 7455; and Jack Kelly, “Men Fooler Blues,” Vocalion 05312), but also as a song of prowess by women, as in Geeshie Wiley’s 1930 "Skinny Legs Blues": "I've got somethin' underneath really works like a boe hog's eye" (Paramount 13074).

${ }^{77}$ J. E. Uhl, "The Prince of New Orleans Piano: How James Booker Missed the Boat but Made the Parade," New England Review 35, no. 3 (2014): 42-60, https://doi.org/10.1353/ner.2014.0134. 
explicit language Morton would have performed in public earlier, as he did for Alan Lomax in $1938 .^{78}$ One hears Morton's genius for composition, and Toussaint's for performance, but nothing of Morton the rough and flamboyant pimp, gambler, and pool shark. Toussaint's original compositions were rhythmically propulsive, tailored to the growing pop charts from the late 1950s, and then funky, but overwhelmingly lyrically anodyne. The assignments of energy were culturally transgressive, but they tamed oppositional messages.

\section{"Here's was among the first blues that I've ever heard"-Jelly Roll Morton.}

"Yes We Can Can's" musical lineage involves connections on the one hand to New Orleans blues and jazz and the commerce in pleasure, and, on the other, to the local civil rights struggle that issued in the historic defeat embodied in the 1896 Supreme Court decision of Plessy v. Ferguson, which legalized racial segregation. Indeed, the brothel was a crucible for musical innovation, and the profits of pleasure commerce sustained political initiatives. Jelly Roll Morton's relations with Mamie Desdunes furnish a point of entry. ${ }^{79}$ In his 1938 Library of Congress recordings and in his last recording sessions a year later, Morton identified Desdunes as having played the first blues song he learned. She lived near Morton's godmother, and to learn the song, Morton acted as "the can rusher," the kid who ran to the tavern for beer, probably while Desdunes hosted a garden party. The commercial version of the song, as "Mamie's Blues," (or "2:19 Train") became a jazz standard, while the earlier version contained the habanero beat Morton called "the Spanish tinge," a precondition for what he considered to be real jazz. Both versions are sex trade songs and it is perhaps Desdunes who first wrote the street walker's lament: "I stood on the corner, my feet was dripping wet. ... I asked every man I met / Can't give me a dollar, give me a lousy dime. . . Just to feed that hungry man of mine." 80

Born Marie Celeste Desdunes (1879-1911), Mamie made her living in the red-light district: as

Emily Landau points out, musicians of color of whatever class background had few other options. ${ }^{81}$ She was reputedly enormously popular. Lawrence Gushee shows that Morton's godmother was living near Desdunes in 1900-1: she was playing something recognizable as blues well before the genre was solidified

\footnotetext{
${ }^{78}$ Jelly Roll Morton, Complete Library of Congress Sessions (Rounder Records, 2005), 1656, Track 7, “Dime's worth of beefsteak and a nickel's worth of lard, / Get a dime's worth of beefsteak and a nickel's worth of lard, / Yes, a dime's worth of beefsteak, nickel's worth of lard, / I'll salivate your pussy till my peter get hard, / I'm the winin' boy, don't deny my name," and so on. ${ }^{79}$ Pace Tony Bolden, "Groove Theory," here the politics of music are not in the groove, but in the involvement of players in movement politics.

${ }^{80}$ Morton, Library of Congress Sessions, 1688A,Track 4; Rudi Blesh, They All Played Ragtime (New York: Oak Publications, 1966), 179. "One of the authentic masterpieces of music," Desdunes's brilliant three-fingered riff spread through the blues repertoire: we hear it, for instance, in Blind John Davis's late 1930s recordings with Memphis Minnie such as "Keep on Sailing," (Vocalion 03651). Marybeth Hamilton, "Sexuality, Authenticity and the Making of the Blues Tradition," Past and Present, no. 169 (2000): 132-60, https://doi.org/10.1093/past/169.1.132, points to the significance of Morton and of Desdunes in the bawdy, libertine past of the blues. She also dissects the dominant figuration of the blues as the music of troubled male troubadours, to the exclusion of women and women's sexual power. Marybeth Hamilton, In Search of the Blues: Black Voices, White Visions (London: Jonathan Cape, 2007); Elijah Wald, The Blues. A Very Short Introduction (New York: Oxford University Press, 2010), 82-3, https://doi.org/10.1093/actrade/9780195398939.001.0001. On the importance of white supremacist terror in blues history, see Adam Gussow, Seems Like Murder Here: Southern Violence and the Blues Tradition (Chicago: University of Chicago Press, 2002), https://doi.org/10.7208/chicago/9780226311005.001.0001.

${ }^{81}$ Emily Epstein Landau, Spectacular Wickedness: Sex, Race, and Memory in Storyville, New Orleans (Baton Rouge: Louisiana State University Press, 2013).
} 
on the vaudeville circuit. ${ }^{82}$ What is significant in this matter in relation to Williams's analysis of selective tradition, oppositional, alternative, residual, and emergent cultural forms are the immanent relations that join pleasure commerce, race, class, and political critique. Most jazz and blues history has tended to shunt musical creativity and political hegemony away from the complex realities of pleasure commerce. Such was also Obama's engagement with rap and hip hop and the nature of the selections in campaign playlists. Landau points out that the conjunction of jazz and black culture menaced both bourgeois morality and white supremacy:

... the development of the idea of jazz as a form of high art has also been a process of selective remembering and forgetting. Early jazz was raunchy and raw, and its music and lyrics celebrated the low, the physical, and the forbidden: sex, violence, prostitution, and infidelity. What's more, much of it was blatantly and unabashedly misogynistic. This is not to say that the music did not contain and showcase genius; nor is it to say that all practitioners were pimps and misogynists, though some clearly were. There were also women jazz artists, and their songs of sex, desire, and betrayal (of their husbands as well as of themselves) are also worth recollecting along with the women who worked as prostitutes in the district. ${ }^{83}$

One should stress that women who sold pleasure also made music and composed songs about their work in which there is no sense of self-betrayal; rather, pride and prowess frequently dominate. ${ }^{84}$

The challenges pleasure commerce presented to bourgeois morality and to hegemonic sexualities were ambiguous, but counter-hegemonic politics was part of the matrix. Mamie Desdunes was an "outside child" of the Creole community leader Rodolphe Desdunes, for most of his working life a Customs House clerk. ${ }^{85}$ The elder Desdunes was involved in political agitation against post-Reconstruction attempts to reinstall segregation in New Orleans. As one of the founding members of the Comite des Citoyens, Desdunes was at the center of efforts to overthrow the 1890 Segregated Car Act, and it was Mamie's older brother, the musician Daniel Desdunes, who was chosen to launch the test case by boarding an interstate train car and refusing to move to the colored section when challenged. The Comite won the case, but only because the court ruled that the Act did not apply to interstate trains. It was then that the shoemaker Homer Plessy boarded a first class carriage on an intrastate train and was forcibly removed, leading eventually to the Supreme Court decision in Plessy vs Ferguson enshrining the "separate but equal" principle at the heart of Jim Crow politics. ${ }^{86}$ Daniel Desdunes, who moved to Omaha and dominated the music scene there for most of his life, was a well-known jazz musician and composer of such early tunes as 1912's "Happy Feeling Rag." His son Clarence returned to New Orleans in the 1920s and led the group the Joyland Revelers, whose pianist in 1928 was the bluesman Little Brother Montgomery. ${ }^{87}$ It is highly likely that Tuts Washington was familiar with Clarence Desdunes.

\footnotetext{
${ }^{82}$ Lawrence Gushee, “A Preliminary Chronology of the Early Career of Ferd 'Jelly Roll' Morton,” American Music 3, no. 4 (1985): 389-412, 392-3, https://doi.org/10.2307/3051827. On early blues history, see Lynn Abbott and Doug Seroff, The Original Blues: The Emergence of the Blues in African American Vaudeville (Jackson: University Press of Mississippi, 2017). ${ }^{83}$ Landau, Spectacular Wickedness, 176.

${ }^{84}$ Lucille Bogan's song book contains many examples of the sub-genre of sex trade music, including much-covered classics such as “Sweet Patunia” (Paramount 12459); “Tricks Ain't Walkin' No More” (Brunswick 7186); and “Alley Boogie” (Brunswick 7210). Bogan never voices regret or self-doubt; rather, she proclaims her astonishing sexual power and prowess. See Angela Y. Davis, Blues Legacies and Black Feminism: Gertrude "Ma" Rainey, Bessie Smith, and Billie Holiday (New York: Random House, 1998), on the ways in which the social power of black women in America has been at once sexual power.

${ }^{85}$ Of Haitian origin, he was also the author of widely-read history of the Creole population. R.-L. Desdunes, Nos Hommes et Notre histoire. Notices biographiques accompagnées de reflexions et de souvenirs personnels. Hommage à la population créole, en souvenir des grands hommes qu'elle a produits et des bonnes choses qu'elle a accomplies (Montreal: Arbour \& Dupont, 1911).

${ }^{86}$ Dan Vernhettes and Peter Hanley, “The Desdunes Family,” The fazz Archive 27 (2014): 25-45, 25-6.

${ }^{87}$ Vernhettes and Hanley, "Desdunes Family", 27-38.
} 
In other American cities, vernacular music-making, pleasure commerce, racial politics, the production of wealth, and urban political dominance were intimately connected for much of the late nineteenth and first half of the twentieth centuries at least. ${ }^{8}$ Some powerful and respected black civic leaders, such as Robert Reed Church of Memphis, made their fortunes from pleasure commerce, used their wealth to fund social improvement for the black population, and educated their offspring. Church's daughter, Mary Church Terrell, was a leader in struggles for the franchise and charter member of the NAACP. ${ }^{89}$

More generally, the link between pleasure commerce and political critique is not simply haphazard. Those engaged in pleasure-work commonly act across lines of race and class and so may gain unique insight into the moral hypocrisy of hegemonic domination. There are celebrated historical instances: Colin Jones for instance, shows that Olympe de Gouges, Etta Palm, Claire Lacombe and Théroigne de Méricourt, the "founding parents of French feminism[,] all had a libertine identity prior to the Revolution." ${ }^{90}$ Courtesans all, they attacked the Revolution's policy of installing bourgeois marriage-at the cost of their lives.

\section{Conclusion}

My account of "Yes We Can Can" shows that subaltern music-making contains emergent and oppositional elements at particular moments in its genealogy. In early blues and jazz, the unbridled ribaldry and explicit celebrations of sexual power and prowess, not less than the documenting of the difficult conditions of pleasure work, expressed the force and creativity of subaltern culture at the same time as they shocked conventional middle-class observers, black and white: W.C. Handy, who "fumigated" the brothel music he learned, and Howard Odum and Guy Johnson, who recoiled at popular songs that "tell of every phase of immorality and vice and filth" that "represent the superlative of the repulsive." 11 These musical forms and practices were in complex relations with struggles against Jim Crow. In the ongoing struggle for cultural hegemony in the United States, racist practice segregated subaltern musical production and performance in "race record" catalogues and in "darktown" venues, giving access to wider commodity markets only if meanings were encoded. But these segregated and encoded spaces allowed for the expression of counter-hegemonic discourses-with respect to women's power and sexuality, for instance, against official treatment of sexually active women as disease vectors. When they crossed over into dominant culture, they were defanged in a process described by Guy Johnson as coming "up out of the slime."

Naturally the everyday songs of the Negro adventurer and roustabout abounded in suggestiveness and indecency. Houses of prostitution, gambling dens, and other resorts,

\footnotetext{
${ }^{88}$ For Chicago, see Cynthia M. Blair, I've Gotta Make My Livin': Black Women's Sex Work in Turn-of-the-Century Chicago (Chicago: University of Chicago Press, 2010), https://doi.org/10.7208/chicago/9780226056005.001.0001; Kenney, Chicago Fazz; Walter Reckless, Vice in Chicago (Montclair, NJ: Patterson Smith 1969 [1933]). For Dallas, see Alan B. Govenar and Jake F. Brakefield, Deep Ellum and Central Track: Where the Black and White Worlds of Dallas Converged (Denton: University of North Texas Press, 1998). For New York, see Timothy J. Gilfoyle, City of Eros: New York City, Prostitution, and the Commercialization of Sex, 1790-1920 (New York: W. W. Norton \& Company, 1992).

${ }^{89}$ Preston Lauterbach, Beale Street Dynasty: Sex, Song, and the Struggle for the Soul of Memphis (New York: W.W. Norton \& Company, 2015). Margaret McKee and Fred Chisenhall, Beale Black and Blue: Life and Music on Black America's Main Street (Baton Rouge: Louisiana State University Press, 1993).

${ }^{90}$ Colin Jones, "Presidential Address: French Crossings IV: Vagaries of Passion and Power in Enlightenment Paris," in

Transactions of the Royal Historical Society, Series 6, no. 23, 31, https://doi.org/10.1017/S0080440113000029.

${ }^{91}$ Handy, Father of the Blues, 82; Odum and Johnson, The Negro and His Songs, 126.
} 
especially in the cities along the Mississippi, were the clearing houses for such songs. Some of these songs of the Negro underworld have made the ascent into the realm of decency. In the lowest type of cabarets they can be heard in their original versions. Passing up through the various grades of cabarets and vaudeville shows, they lose objectionable words and phrases here and there until they finally become either decent or indecent, as you will. Then song writers, white and black, adopt them and alter them just enough to "get by." 92

"Yes We Can Can" is implicated in a shifting structure of feeling at the moment of its composition, certified by the changed denotation and connotation of "funk" and "funky" and by the surge of energy into a novel cultural form. This shift was part of a complex transformation provoked by the social movements from the 1960s and early 1970s, where "black" challenged "negro," "gay" challenged "faggot," and "Ms." took over from "Miss." The lexical changes were bound up with the changing forms of solidarity embodied in social movement activity. Yet these shifts were also subject to incorporation, especially through commercial success. Funk in music authorizes visceral pleasures but political critique remains buried.

In terms of Raymond Williams's political ambitions, one can read the 2008 Obama campaign as the clever engineering of a musical-political coalition through the selective mobilization of tradition. Moving, dancing, and chanting together in familiar media promoted real, if limited, forms of solidarity. Hope for a better world was broadly evocative, if lacking in substance, and leadership involved the defanging of oppositional cultural elements. Songs of unabashed ribaldry and of irreligion, the rough elements of hip hop, and the critical commentary in soul and funk were excluded. Music in the groove of love, hope, and optimism evoked elements of a structure of feeling, a surge of energy and enthusiasm into a cultural form, but in a significantly vague manner. The groove could accommodate all manner of aspirations, but without detailing the structural transformations necessary to create durable democratic and post-racial solidarity. Could a political-musicologist have anticipated that the campaign's exclusion of messages of ribaldry and rage foreshadowed Obama's fantasy of a non-partisan, moderately progressive agenda? None seems to have done so.

\section{Bibliography}

Abbott, Lynn, and Doug Seroff. The Original Blues: The Emergence of the Blues in African American Vaudeville. Jackson: University Press of Mississippi, 2017.

Alexander, Jeffrey C. The Performance of Politics: Obama's Victory and the Democratic Struggle for Power. New York: Oxford University Press, 2010.

Baraka, Amiri (LeRoi Jones). Blues People: Negro Music in White America. New York: William Morrow and Company, 1963.

Best, Beverley. "Raymond Williams and the Structure of Feeling of Reality TV." International Journal of Humanities and Social Science 2, no. 7 (2012): 192-201.

Blair, Cynthia M. I've Got to Make My Livin': Black Women's Sex Work in Turn-of-the-Century Chicago. Chicago: University of Chicago Press, 2010. https://doi.org/10.7208/chicago/9780226056005.001.0001.

${ }_{92}$ G. B. Johnson, "Double meaning in the popular negro blues," The fournal of Abnormal and Social Psychology 22, no. 1 (1927): 12-20, 18, https://doi.org/10.1037/h0075493. 
Blim, Richard Daniel. "Patchwork Nation: Collage, Music, and American Identity." Ph.D. diss., University of Michigan, 2013.

Bolden, Tony. "Groove Theory: A Vamp on the Epistemology of Funk." American Studies 52, no. 4 (2013): 9-34. https://doi.org/10.1353/ams.2013.0114.

- "The Funk Aesthetic in African American Poetry." In Black Music, Black Poetry: Blues and Jazz's Impact on African American Versification, edited by Gordon E. Thompson, 79-90. New York: Routledge, 2014.

Broonzy, Big Bill. “Get Back (Black, Brown and White) 1945.” Black Brown and White Mercury 842743 2, 1991.

Broonzy, Big Bill, and Yannick Bruynoghe. Big Bill Blues. New York: De Capo Press, 1992.

Brothers, Thomas. Louis Armstrong's New Orleans. New York: W. W. Norton \& Company, 2006.

Brown, Jayna. Babylon Girls: Black Women Performers and the Shaping of the Modern. Durham, NC: Duke University Press, 2008. https://doi.org/10.1215/9780822390695.

Carpenter, Cheris A. "The Obamachine: Technopolitics 2.0." Journal of Information Technology \& Politics 7, no. 2-3 (2010): 216-25. https://doi.org/10.1080/19331681003765887.

Chartier, Roger. "The practical impact of writing." In A History of Private Life, edited by Roger Chartier, 111-65. Cambridge, MA: Harvard University Press, 1989.

Clarke, John. "Subordinating the Social? Neo-liberalism and the remaking of welfare capitalism." Cultural Studies 21, no. 6 (2007): 974-87. https://doi.org/10.1080/09502380701470643.

Cochrane, Tom. "Joint Attention to Music." British Journal of Aesthetics 49, no. 1 (2009): 59-73. https://doi.org/10.1093/aesthj/ayn059.

Cogburn, Derrick L., and Fatima K. Espinoza-Vasquez. "From Networked Nominee to Networked Nation: Examining the Impact of Web 2.0 and Social Media on Political Participation and Civic Engagement in the 2008 Obama Campaign." Journal of Political Marketing 10, no. 1-2 (2011): 189213. https://doi.org/10.1080/15377857.2011.540224.

Coleman, Rebecca. "Theorizing the present: digital media, pre-emergence and infra-structures of feeling." Cultural Studies 32, no. 4 (2018): 600-22. https://doi.org/10.1080/09502386.2017.1413121.

Curtis, Bruce. "How Much and How Not to Explain: Gestural Referencing and Conceptual Misappropriations." Canadian Journal of Sociology/Cahiers canadiens de sociologie 40, no. 2 (2015): 223-40, https://doi.org/10.29173/cjs24993.

. "'I can tell by the way you smell': Dietetics, Smell, Social Theory." The Senses and Society3, no. 1 (2008): 5-22. https://doi.org/10.2752/174589308X266434.

Danielson, Anne. Presence and Pleasure: The Funk Grooves of James Brown and Parliament. Middletown, CT: Wesleyan University Press, 2006.

Davis, Angela Y. Blues Legacies and Black Feminism: Gertrude "Ma" Rainey, Bessie Smith, and Billie Holiday. New York: Random House, 1998.

Desdunes, Rodolphe Lucien. Nos Hommes et Notre histoire. Notices biographiques accompagnées de reflexions et de souvenirs personnels. Hommage à la population créole, en souvenir des grands hommes qu'elle a produits et des bonnes choses qu'elle a accomplies. Montreal: Arbour \& Dupont, 1911.

Doleac, Benjamin. "Strictly Second Line: Funk, Jazz, and the New Orleans Beat." Ethnomusicology Review 18 (2013), 1-16. 
Foucault, Michel. The Birth of Biopolitics: Lectures at the Collège de France, 1978-1979. Translated by Graham Burchell. New York: Palgrave Macmillan 2008.

Frank, David A. "Obama's Rhetorical Signature: Cosmopolitan Civil Religion in the Presidential Inaugural Address, January 20, 2009.” Rhetoric and Public Affairs 14, no. 4 (2011): 650-30. https://doi.org/10.1353/rap.2011.0044.

Gilfoyle, Timothy J. City of Eros: New York City, Prostitution, and the Commercialization of Sex, 1790 1920. New York: W. W. Norton \& Company, 1992.

Gorzelany-Mostak, Dana. "Keepin' It Real (Respectable) in 2008: Barack Obama's Music Strategy and the Formation of Presidential Identity." Journal of the Society for American Music 10, no. 2 (2016): 113-48. https://doi.org/10.1017/S1752196316000043.

Gorzelany-Mostak, Dana, and James Deaville. "On the Campaign Trail(er): Deconstructing the Soundscape of the 2012 US Presidential Election." Music \& Politics 9, no. 2 (2015): 1-14. https://doi.org/10.3998/mp.9460447.0009.201.

Gosa, Travis L. "Not Another Remix: How Obama Became the First Hip-Hop President." Journal of Popular Music Studies 22, no. 4 (2010): 389-415. https://doi.org/10.1111/j.1533-1598.2010.01252.x.

Gosa, Travis L., and Erik Nielson, eds. The Hip Hop \& Obama Reader. New York: Oxford University Press, 2015. https://doi.org/10.1093/acprof:oso/9780199341801.001.0001.

Govenar, Alan B., and Jake F. Brakefield. Deep Ellum and Central Track: Where the Black and White Worlds of Dallas Converged. Denton: University of North Texas press, 1998.

Gramsci, Antonio. "In Search of the Educational Principle." New Left Review, no. 32 (1965): 53-61.

- The Modern Prince and other writings by Antonio Gramsci. Translated by Louis Marks. London: Lawrence \& Wishart, 1957.

- Selections from the Prison Notebooks. London: Lawrence \& Wishart, 1973.

Greene, Kevin D. “Just a Dream': Big Bill Broonzy, the Blues, and Chicago's Black Metropolis.” Journal of Urban History 40, no. 1 (2014): 116-36. https://doi.org/10.1177/0096144213489261.

Gushee, Lawrence. “A Preliminary Chronology of the Early Career of Ferd 'Jelly Roll' Morton.” American Music 3, no. 4 (1985): 389-412. https://doi.org/10.2307/3051827.

Gussow, Adam. Seems Like Murder Here: Southern Violence and the Blues Tradition. Chicago: University of Chicago Press, 2002. https://doi.org/10.7208/chicago/9780226311005.001.0001.

Hall, Stuart. "The 'Political' and the 'Economic' in Marx's Theory of Classes." In Classes and Class Structure, edited by Alan Hunt, 15-60. London: Lawrence and Wishart, 1977.

_ . "Re-thinking the "Base-and-Superstructure" Metaphor." In The Communist University of London. Papers on Class, Hegemony and Party, edited by Jon Bloomfield, Dave Coutinho, Alan Hunt, and James Klugmann, 43-72. London: Lawrence and Wishart, 1977.

—. "Popular culture, politics and history." Cultural Studies 32, no. 6 (2018): 929-52. https://doi.org/10.1080/09502386.2018.1521623.

Hamilton, Marybeth. "The Blues, the Folk, and African-American History." Transactions of the Royal Historical Society 11 (2001): 17-35. https://doi.org/10.1017/S0080440101000020.

-. In Search of the Blues: Black Voices, White Visions. London: Jonathan Cape, 2007.

—. "On the Trail of Negro Folk Songs." Journal of Popular Music Studies 18, no. 1 (2006): 66-93. https://doi.org/10.1111/j.1524-2226.2006.00076.x. 
. "Sexuality, Authenticity and the Making of the Blues Tradition." Past and Present 169 (2000): 132-60. https://doi.org/10.1093/past/169.1.132.

—. "The Voice of the Blues." History Workshop Journal 54, no. 1 (2002): 123-43. https://doi.org/10.1093/hwj/54.1.123.

Handy, W. C. Father of the Blues: An Autobiography. New York: Macmillan 1970 [1941].

Harding, Jennifer, and E. Deidre Pribram. "The Power of Feeling: Locating Emotions in Culture.” European Journal of Cultural Studies 5, no. 4 (2002): 407-26. https://doi.org/10.1177/1364942002005004294.

Hesmondhalgh, David. Why Music Matters. Oxford: Wiley-Blackwell, 2013.

Hill, Christopher. “Antonio Gramsci.” The New Reasoner, no. 4 (1958): 107-13.

Hoerl, Kristen. "Selective Amnesia and Racial Transcendence in News Coverage of President Obama's Inauguration." Quarterly Journal of Speech 98, no. 2 (2012): 178-202. https://doi.org/10.1080/00335630.2012.663499.

Hoffschwelle, Mary S. “"Better Homes on Better Farms”: Domestic Reform in Rural Tennessee.” Frontiers: A Journal of Women Studies 22, no. 1 (2001): 51-73.

Jakobsen, Janet R., and Ann Pellegrini. “Obama’s Neo-New Deal: Religion, Secularism, and Sex in Political Debates Now.” Social Research: An International Quarterly 76, no. 4 (2009): 1227-54.

Johnson, G. B. "Double Meaning in the Popular Negro Blues.” The Journal of Abnormal and Social Psychology 22, no. 1 (1927): 12-20. https://doi.org/10.1037/h0075493.

Jones, Colin. "Presidential Address: French Crossings IV: Vagaries of Passion and Power in Enlightenment Paris." In Transactions of the Royal Historical Society, 3-36. Cambridge: Cambridge University Press, 2013. https://doi.org/10.1017/S0080440113000029.

Keire, Mara L. For Business and Pleasure: Red-Light Districts and the Regulation of Vice in the United States, 1890-1933. Baltimore: Johns Hopkins University Press, 2010.

—. "Swearing Allegiance: Street Language, US War Propaganda, and the Declining Status of Women in Northeastern Nightlife, 1900-1920." Journal of the History of Sexuality 25, no. 2 (2016): 246-66. https://doi.org/10.7560/JHS25202.

Kelman, Ari Y. "Rethinking the Soundscape." The Senses and Society 5, no. 2 (2010): 212-34. https://doi.org/10.2752/174589210X12668381452845.

Kenney, William Howland. Chicago Jazz: A Cultural History, 1904-1930. New York: Oxford University Press, 1993.

Kirk, John. "Class, Community and 'Structures of Feeling' in Working-Class Writing from the 1980s." Literature \& History 8, no. 2 (1999): 44-63. https://doi.org/10.7227/LH.8.2.4.

Landau, Emily Epstein. Spectacular Wickedness: Sex, Race, and Memory in Storyville, New Orleans. Baton Rouge: Louisiana State University Press, 2013.

Lauterbach, Preston. Beale Street Dynasty: Sex, Song, and the Struggle for the Soul of Memphis. New York: W. W. Norton \& Company, 2015.

Long, Alecia P. The Great Southern Babylon: Sex, Race, and Respectability in New Orleans, 1865-1920. New Orleans: Louisiana State University Press, 2014.

McKee, Margaret, and Fred Chisenhall. Beale Black and Blue: Life and Music on Black America's Main Street. Baton Rouge: Louisiana State University Press, 1993. 
Milner, Andrew. "Cultural Materialism, Culturalism and Post-Culturalism: The Legacy of Raymond Williams." Theory Culture and Society 11 (1994): 43-73. https://doi.org/10.1177/026327694011001005.

Morton, Jelly Roll. The Complete Library of Congress Recordings by Alan Lomax. Rounder Records, 2005 [1938].

Mukerji, Chandra. "Cultural Genealogy: Method for a Historical Sociology of Culture or Cultural Sociology of History." Cultural Sociology 1, no. 1 (2007): 49-71. https://doi.org/10.1177/1749975507073919.

Newton, Huey P. "The Women's Liberation and Gay Liberation Movements.” In The Huey P. Newton Reader, edited by David Hilliard and Donald Weise, 157-9. New York: Seven Stories Press, 2002 [1970].

Obama, Michelle. Becoming. New York: Crown, 2018.

Odum, Howard W., and Guy B. Johnson. The Negro and His Songs: A Study of Typical Negro Songs in the South. Raleigh: University of North Carolina Press, 1925.

Ongiri, Amy Abugo. "Prisoner of Love: Affiliation, Sexuality, and the Black Panther Party." The Journal of African American History 94, no. 1 (2009): 69-86. https://doi.org/10.1086/JAAHv94n1p69. . Spectacular Blackness. The Cultural Politics of the Black Power Movement and the Search for a Black Aesthetic. Charlottesville: University of Virginia Press, 2010.

Perone, James E. The Sound of Stevie Wonder: His Words and Music. Westport, CT: Praeger, 2006.

Rabaka, Reiland. Hip Hop's Amnesia: From Blues and the Black Women's Club Movement to Rap and the Hip Hop Movement. Lanham, MD: Lexington Books, 2012.

Raeburn, Bruce Boyd. “The Storyville Exodus Revisited, or Why Louis Armstrong Didn't Leave in November 1917, Like the Movie Said He Did.” The Southern Quarterly52, no. 2 (2015): 10-33.

Reckless, Walter. Vice in Chicago. Montclair, N.J.: Patterson Smith, 1969 [1933].

Selzer, Linda F. "Barack Obama, the 2008 Presidential Election, and the New Cosmopolitanism: Figuring the Black Body." MELUS 35, no. 4 (2010): 15-37. https://doi.org/10.1093/melus/35.4.15.

Smith, R. J. The One: The Life and Music of James Brown. New York: Gotham Books, 2012.

Steedman, Carolyn. Landscape for a Good Woman: A Story of Two Lives. London: Virago, 1986.

Stewart, Alexander. "'Funky Drummer': New Orleans, James Brown and the Rhythmic Transformation of American Popular Music." Popular Music 19, no. 3 (2000): 293-318. https://doi.org/10.1017/S0261143000000180.

Stewart, James B. "Message in the Music: Political Commentary in Black Popular Music from Rhythm and Blues to Early Hip Hop.” The Journal of African American History90, no. 3 (2005): 196-225. https://doi.org/10.1086/JAAHv90n3p196.

Toussaint, Allen. “Winin' Boy Blues.” The Bright Mississippi. Nonesuch, 480380-2, 2008.

Uhl, J. E. "The Prince of New Orleans Piano: How James Booker Missed the Boat but Made the Parade." New England Review35, no. 3 (2014): 42-60. https://doi.org/10.1353/ner.2014.0134.

Valnes, Matthew. “Janelle Monáe and Afro-Sonic Feminist Funk.” Journal of Popular Music Studies 29 (2017): 1-12. https://doi.org/10.1111/jpms.12224.

. "Taking it higher: the spirituality of sensuality in funk performance." African and Black Diaspora: An International Journal 9, no. 1 (2016): 3-15. https://doi.org/10.1080/17528631.2015.1055654. 
Vernallis, Carol. "Audiovisual Change: Viral Web Media and the Obama Campaign." Cinema Journal50, no. 4 (2011): 73-97. https://doi.org/10.1353/cj.2011.0062.

Vernhettes, Dan, and Peter Hanley. "The Desdunes Family.” The Jazz Archive 27 (2014): 25-45.

Vincent, Rickey. Funk: The Music, the People and the Rhythm of the One. New York: St. Martin's 1996. . Party Music: The Inside Story of the Black Panthers' Band and How Black Power Transformed Soul Music. Chicago: Lawrence Hill Books, 2013.

Wald, Elijah. The Blues: A Very Short Introduction. New York: Oxford University Press, 2010. https://doi.org/10.1093/actrade/9780195398939.001.0001.

—. The Dozens: A History of Rap’s Mama. New York: Oxford University Press, 2012.

Wallsten, Kevin. “Yes We Can': How Online Viewership, Blog Discussion, Campaign Statements, and Mainstream Media Coverage Produced a Viral Video Phenomenon.” Journal of Information Technology \& Politics 7, no. 2-3 (2010): 163-81. https://doi.org/10.1080/19331681003749030.

Williams, Gwyn A. "The Concept of 'Egemonia' in the Thought of Antonio Gramsci: Some Notes on Interpretation." Journal of the History of Ideas 21, no. 4 (1960): 586-99. https://doi.org/10.2307/2708106.

Williams, Raymond. "Base and Superstructure in Marxist Cultural Theory." New Left Review, no. 82 (1973): 3-16.

—. The Country and the City. London: Chatto and Windus, 1973.

—. Culture. Glasgow: Fontana Paperbacks, 1981.

—. "Culture and Technology." In The Politics of Modernism: Against the New Conformists, 11939. London: Verso, 1989.

- Keywords: A vocabulary of society and culture. Revised ed. (Oxford: Fontana Paperbacks, 1983).

- "Language and the Avant Garde." In The Politics of Modernism: Against the New Conformists, 65-80. London Verso, 1989.

—. The Long Revolution. Westport, CT: Greenwood Publishers, 1975.

-. Politics and Letters: Interviews with New Left Review. London: New Left Books, 1979.

_. "Popular culture: history and theory." Cultural Studies 32, no. 6 (2018): 903-28. https://doi.org/10.1080/09502386.2018.1521620.

—. Problems in Materialism and Culture: Selected Essays. London: Verso, 1980. . "The Uses of Cultural Theory." In The Politics of Modernism: Against the New Conformists, 162-76. London: Verso, 1989.

Zembylas, Michalinos. "'Structures of Feeling' in Curriculum and Teaching: Theorizing the Emotional Rules." Educational Theory 52, no. 2 (2002): 187-208. https://doi.org/10.1111/j.1741$\underline{5446.2002 .00187 . x}$. 


\section{Acknowledgements}

My thanks to Alan Hunt, Michael D. Rodriguez, Justin Paulson, Mythili Rajiva, Rhys Steckel, John Shepherd, and Jesse Stewart for engaging with drafts of this article; to two anonymous reviewers for their constructive criticism, and to Gabriela Cruz for editorial commentary. 